\title{
AKURASI TAKSIRAN BERAT BADAN JANIN DAN BAYI BARU LAHIR MENURUT JOHNSON THAUSACK DAN POSISI SEMI FOWLER
}

\author{
Epa Hermawati ${ }^{1}$, Atit Tajmiati ${ }^{2}$, \& Etin Rohmatin ${ }^{3}$ \\ ${ }^{1}$ Alumni Prodi D-IV Kebidanan Poltekkes Kemenkes Tasikmalaya \\ ${ }^{2,3}$ Staf Dosen Kebidanan Poltekkes Kemenkes Tasikmalaya
}

\begin{abstract}
Abstrak
Tujuan penelitian untuk mengetahui akurasi hasil taksiran berat badan janin menurut Johnson Thausack dengan berat badan bayi baru lahir menggunakan posisi semi fowler. Rancangan penelitian menggunakan rancangan eksperimen dengan pre-eksperimen design, dengan pendekatan one-shot case study. Populasinya adalah semua ibu inpartu kala I di Wilayah Kerja Puskesmas Cibeureum Tasikmalaya pada bulan Januari - Maret 2017. Pengambilan sampel dalam penelitian ini menggunakan purpossive sampling yang berjumlah 36 orang. Sebelumnya dilakukan uji normalitas data dan hasilnya data berdistribusi normal dengan $\mathrm{p}$ value $0,288(\mathrm{p}>0,05)$. Analisa data yang digunakan adalah uji pearson. Hasil penelitian diperoleh nilai $\rho=0,074(\mathrm{p}<0,05)$, hal ini menyatakan tidak terdapat perbedaan antara taksiran berat badan janin rumus johnson thausack dengan berat badan bayi lahir menggunakan posisi semi fowler. Taksiran berat badan janin merupakan salah satu tugas yang penting bagi bidan maupun praktisi lainnya untuk dapat memprediksi salah satu kesulitan persalinan yang akan dialami oleh ibu hamil.
\end{abstract}

Kata Kunci: taksiran berat badan janin, semi fowler, johnson thausack.

\begin{abstract}
The purpose of study was to determine the accuracy of fetal weight estimation according to johnson thausack with newborn weight using semi fowler position. The design of this study is an experimental with pre-experiment design, with one-shot case study approach. The population is all mothers inpartu kala I in Working Area Puskesmas Cibeureum Tasikmalaya in January-March 2017. Sampling in this study using purpossive sampling which amounted to 36 people. Previously tested the normality of data and the results of normal distribution data with $p$ value $0.288(\rho>0,05)$. Analysis of data used is pearson test. The results obtained by the value of $\rho=0.074(p<0.05)$, this states that there is no difference between estimated fetal body weight of Johnson Thausack formula and weight of babies born using a semi-fowler position. Estimated fetal weight is one of the important tasks for midwives and other practitioners to be able to predict one of the difficulties of labor that will be experienced by pregnant women.
\end{abstract}

Keywords: estimated fetal weight, semi-fowler, Johnson Thausack.

\section{PENDAHULUAN}

Menurut World Health Organization (WHO), pada tahun 2013 Angka Kematian Bayi (AKB) di dunia 34 per 1.000 kelahiran hidup, di negara berkembang 37 per 1.000 kelahiran hidup, dan di negara maju 5 per 1.000 kelahiran hidup. AKB di Asia Timur 11 per 1.000 kelahiran hidup, Asia Selatan 43 per 1.000 kelahiran hidup, Asia Tenggara 24 per 1.000 kelahiran hidup dan Asia Barat 21 per 1.000 kelahiran hidup (WHO, 2014).

Penyebab AKB menurut WHO kirakira 3\% (3,6 juta) dari 120 juta bayi lahir mengalami asfiksia, hampir 1 juta bayi ini kemudian meninggal. $\mathrm{Di}$ Indonesia dari seluruh kematian bayi, sebanyak $57 \%$ meninggal pada masa bayi baru lahir (usia dibawah 1 bulan) dan setiap 6 menit terdapat 1 bayi baru lahir di Indonesia adalah bayi berat lahir rendah (29\%), asfiksia (27\%) dan lain-lain 44\% (JNPK-KR, 2008).

Pada tahun 2013 AKB di Indonesia mencapai 25 per 1.000 kelahiran hidup. Bila dibandingkan dengan Malaysia, Filipina dan Singapura, angka tersebut lebih besar 
dibandingkan dengan angka dari negara negara tersebut dimana AKB Malaysia 7 per 1.000 kelahiran hidup, Filipina 24 per 1.000 kelahiran hidup dan Singapura 2 per 1.000 kelahiran hidup (WHO, 2014).

Survey Demografi Kesehatan Indonesia (SDKI) juga mencatat bahwa partus lama merupakan penyebab kesakitan dan kematian maternal dan perinatal utama disusul oleh perdarahan, panas tinggi dan eklampsia. Hal ini menggambarkan pentingnya pertolongan persalinan oleh tenaga kesehatan yang terampil, melalui pemeriksaan pada ibu hamil dan pengukuran taksiran berat badan janin. Karena sebagian besar komplikasi terjadi pada saat persalinan (SDKI, 2012).

Sekitar 90\% kematian ibu terjadi disaat persalinan dan kira-kira $95 \%$ dari penyebab kematian ibu tersebut adalah komplikasi obstetrik yang sering tidak dapat diperkirakan sebelumnya. Salah satunya penyulit dalam proses persalinan akibat adanya distosia, diantaranya power (kekuatan kontraksi uteri), passage (Jalan lahir), passanger (janin/berat janin). Maka taksiran berat janin mempunyai arti yang sangat penting. Berat bayi yang sangat kecil atau sangat besar berhubungan dengan meningkatnya komplikasi selama masa persalinan dan nifas. Yang paling sering terjadi pada janin dengan berat lahir besar (makrosomia) salah satunya adalah distosia bahu. Sedangkan pada ibu dapat terjadi perlukan jalan lahir, trauma pada otot-otot dasar panggul dan perdarahan pasca persalinan. Pada bayi dengan berat lahir rendah dapat terjadi respiratory distress syndrom atau hipoglikemi (Winkjosastro 2008).

Berdasarkan kenyataan diatas, perlu dipikirkan cara-cara untuk mendeteksi kesejahteraan janin termasuk perkiraan berat badan janin selama masa kehamilan dan saat persalinan, mengingat sebanyak $10 \%-20 \%$ dari seluruh proses kehamilan dan persalinan dapat mengalami komplikasi.Bagi penolong persalinan seperti bidan, berat badan bayi mempunyai arti yang sangat penting dalam menentukan saat rujukan.

Apabila ditemukan tinggi fundus uteri (TFU) $40 \mathrm{~cm}$ atau lebih yang mengindikasikan terjadinya makrosomia atau bayi besar yang merupakan salah satu faktor presdiposisi terjadinya distosia bahu dan perdarahan paska persalinan sebaiknya pasien dirujuk. Bagi obstetrikus, taksiran berat badan bayi sangat dirasakan kepentingannya saat harus menentukan tindakan persalinan apakah secara pervaginam ataupun perabdominal (Depkes $\mathrm{RI}$, 2007).

Taksiran berat badan janin intra uterin salah satunya bisa dilakukan dengan pengukuran tinggi fundus uteri. Taksiran berat badan janin intra uterin mempunyai arti penting dalam penatalaksanaan persalinan. Ketepatan penaksiran berat badan lahir, akan mempengaruhi ketepatan penatalaksanaan persalinan dan hasilnya sehingga diharapkan dapat mengurangi kematian dan kesakitan pada persalinan (Cuningham, 2006).

Akurasi adalah tingkat kedekatan pengukuran terhadap nilai yang sebenarnya (International Vocabulary of Metrology, 2008). Taksiran berat janin adalah salah satu cara menafsir berat janin ketika masih di dalam uterus (Kusmiati, 2008). Taksiran ini berguna untuk memantau pertumbuhan janin dalam rahim, sehingga dapat mendeteksi dini kemungkinan terjadinya pertumbuhan janin yang abnormal. Terdapat beberapa cara untuk menentukan taksiran berat janin yaitu: dengan cara palpasi, dengan menggunakan rumus Johnson Thousack, dengan rumus Formula Dare's, rumus Niswander, dan USG. Tinggi fundus uteri mempunyai hubungan yang kuat dengan berat badan bayi serta mampu merefleksikan pertumbuhan janin serta ukuran fetus (Julianty, Yola dan Azis, 2006).

Menurut Wheeler (2014), apabila tinggi fundus 3 sampai $4 \mathrm{~cm}$ lebih kecil dari normal, kemungkinan retardasi pertumbuhan intrauterin terhambat, presentasi sungsang, infeksi janin, abnormalitas kromosom atau genetik, 
penurunan bagian presentasi ke pelvis, kematian janin, atau oligohidramnion (jumlah cairan amnion sedikit). Sedangkan apabila tinggi fundus melebihi sekitar 3 sampai $4 \mathrm{~cm}$ dari normal, kemungkinan bayi makrosomia karena ibu menderita diabetes, gestasi multipel, bayi yang secara konstitusional besar, dan polihidramnion (cairan amnion berlebih). Sehingga salah satu cara sederhana memantau pertumbuhan dan perkembangan janin dapat dilakukan dengan menghitung TBJ melalui pengukuran TFU terlebih dahulu.

Posisi fowler adalah posisi setengah duduk atau duduk, dimana bagian kepala tempat tidur lebih tinggi atau dinaikkan. Posisi ini dilakukan untuk mempertahankan kenyamanan dan memfasilitasi fungsi pernapasan pasien.

Berdasarkan hasil studi pendahuluan terdapat 5 orang sampel 3 diantaranya taksiran berat badan janin lebih mendekati berat badan bayi lahir menggunakan posisi semi fowler. sedangkan 2 orang lebih mendekati berat badan bayi lahir menggunakan posisi supinasi. Maka peneliti tertarik untuk melakukan penelitian mengenai akurasi hasil taksiran berat badan janin dengan berat badan bayi lahir menggunakan posisi semi fowler di Wilayah Kerja Puskesmas Cibeureum Tasikmalaya Tahun 2017.

\section{METODOLOGI PENELITIAN}

Rancangan penelitian menerapkan rancangan pre-eksperimen design, dengan pendekatan one-shot case study (studi kasus tembakan). Penelitian dilakukan di wilayah kerja Puskesmas Cibeureum Kota Tasikmalaya pada bulan 03 Januari - 20 Maret 2017.

Populasi dalam penelitian ini semua ibu ipartu kala I di wilayah kerja Puskesmas Cibeureum Tasikmalaya. Waktu penelitian dari bulan Januari - Maret 2017. Teknik pengambilan sampel menggunakan purposive sampling. Besaran sampel yang diperoleh sebanyak 36 responden, dan telah memenuhi kriteria yang ditentukan peneliti yaitu ibu ipartu kala I fisiologis di wilayah kerja Puskesmas Cibeureum Tasikmalaya, bersedian terlibat dalam penelitian.

Pada penelitian ini peneliti menggunakan daftar tabel yang terdiri dari hasil pengukuran TFU menggunakan posisi semi fowler, hasil TBBJ menggunakan rumus Johnson Thausack dan selisih dari berat badan bayi lahir dengan TBBJ. Analisa data yang dilakukan adalah analisa univariat dan analisa bivariat dengan menggunaan rumus pearson correlation.

\section{HASIL PENELITIAN}

Tabel 1. Distribusi Frekuensi Hasil Pengukuran TFU Menggunakan Posisi Semi fowler

\begin{tabular}{ccc}
\hline TFU (cm) & $\mathbf{f}$ & $\%$ \\
\hline 28 & 4 & 11,1 \\
\hline 29 & 3 & 8,3 \\
\hline 30 & 7 & 19,4 \\
\hline 31 & 8 & 22,2 \\
\hline 32 & 7 & 19,4 \\
\hline 33 & 6 & 16,7 \\
\hline 34 & 1 & 2,9 \\
\hline Jumlah & 36 & 100 \\
\hline
\end{tabular}

Berdasarkan tabel 1. menunjukan bahwa hasil pengukuran TFU menggunakan posisi semi fowler yaitu TFU $28 \mathrm{~cm}$ terdapat 4 orang $(11,1 \%)$, TFU $29 \mathrm{~cm}$ terdapat 3 orang $(8,3 \%)$, TFU $30 \mathrm{~cm}$ terdapat 7 orang $(19,4 \%)$, TFU $31 \mathrm{~cm}$ terdapat 8 orang $(22,1 \%)$, TFU $32 \mathrm{~cm}$ terdapat 7 orang $(19,4 \%)$, TFU $33 \mathrm{~cm}$ terdapat 6 orang $(16,4 \%)$ dan TFU $34 \mathrm{~cm}$ terdapat 1 orang $(2,9 \%)$.

Tabel 2. Distribusi Frekuensi TBBJ Menggunakan Rumus Perhitungan Johnson Thausack

\begin{tabular}{ccc}
\hline TBBJ (gram) & $\mathbf{f}$ & $\%$ \\
\hline$\leq 2500$ & 3 & 8,3 \\
\hline $2500-4000$ & 33 & 91,7 \\
\hline$\geq 4000$ & 0 & 0 \\
\hline Jumlah & 36 & 100 \\
\hline
\end{tabular}

Berdasarkan tabel 2 menunjukan bahwa hasil perhitungan TBBJ menggunakan rumus Johnson Thausack yaitu 
rentang $2500-4000$ gram terdapat 33 orang $(91,7 \%)$.

Tabel 3. Distribusi Frekuensi Berat Badan Bayi Lahir

\begin{tabular}{ccc}
\hline BBBL (gram) & $\mathbf{F}$ & $\%$ \\
\hline$\leq 2500$ & 0 & 0 \\
\hline $2500-4000$ & 36 & 100 \\
\hline$\geq 4000$ & 0 & 0 \\
\hline Jumlah & 36 & 100 \\
\hline
\end{tabular}

Berdasarkan tabel 4.3 menunjukan bahwa berat badan bayi lahir menggunakan rumus Johnson Thausack yaitu BBBL 25004000 gram terdapat 36 orang (100\%).

Tabel 4. Hasil Tabulasi Silang Akurasi

Taksiran Berat Badan Janin dan Berat Badan Bayi Lahir

\begin{tabular}{ccc}
\hline Variabel & \multicolumn{2}{c}{$\begin{array}{c}\text { Berat Badan } \\
\text { Bayi Lahir }\end{array}$} \\
\hline Taksiran Berat Badan Janin & $\mathrm{n}$ & $p$ value $^{*}$ \\
\cline { 2 - 3 } $\begin{array}{c}\text { Dengan Berat Badan Bayi } \\
\text { Lahir }\end{array}$ & 36 & 0,074 \\
\hline$\rho$ dari uji pearson & & \\
\hline
\end{tabular}

Pada tabel 4 diperoleh nilai $\rho=$ 0,074 dengan nilai $p$ value 0,05 . Jadi $0.74>$ 0.05 maka tidak terdapat perbedaan taksiran berat badan jain dengan berat badan bayi lahir.

\section{PEMBAHASAN}

Menurut Vivian, (2010) menyatakan perkiraan TFU dari hasil penelitian menunjukkan hal-hal berikut: pengukuran menggunakan pita pengukur memberikan hasil yang konsisten antar individu (walaupun masih terjadi sedikit variasi). TFU pada kehamilan lanjut atau saat persalinan dalam posisi terlentang, terbukti memberikan hasil yang lebih tinggi dari yang sebenarnya sehingga hal tersebut menyebabkan perkiraan umur kehamilan yang salah. Program nasional menganjurkan posisi setengah duduk pada saat pengukuran TFU diukur dengan menggunakan pita ukur standar untuk memberikan interpretasi pertumbuhan janin benar. Pengukuran TFU bila dilakukan oleh petugas yang sama setiap kunjungan terbukti memiliki nilai prediktif yang baik terutama mengidentifikasi adanya gangguan pertumbuhan intra uteri.

Hasil penelitian menunjukan bahwa

TBBJ menggunakan rumus Johnson Thausack TBBJ yaitu TBBJ $\leq 2500$ gram terdapat 3 orang $(8,3 \%)$ dan TBBJ 2500 4000 gram terdapat 33 orang $(91,7 \%)$. Berat badan penting diukur sebelum proses persalinan mulai, gunanya untuk mengantisipasi kemungkinan penyulit kehamilan, persalinan seperti gangguan pertumbuhan bayi atau makrosomia (Bayi Besar).

Taksiran berat badan janin merupakan salah satu tugas yang penting bagi bidan maupun praktisi lainnya untuk dapat memprediksi salah satu kesulitan persalinan yang akan dialami oleh ibu hamil atau upaya apa yang bisa dilakukan oleh bidan jika justru yang bermasalah adalah bayi yang baru lahir,sehingga dengan diketahuinya perkiraan berat bayi lahir bidan akan dapat melakukan persiapan persalinan lebih baik, apakah persiapan untuk ibu atau bayi yang akan lahir, disamping kesulitan lainnya misalnya kadar $\mathrm{Hb}$, lebar panggul dan riwayat persalinan sebelumnya.

Hasil penelitian menunjukan bahwa berat badan bayi lahir menggunakan rumus Johnson Thausack yaitu BBBL 2500-4000 gram terdapat 36 orang (100\%). Berat bayi lahir adalah berat badan bayi yang di timbang dalam waktu 1 jam pertama setelah lahir. Hubungan antara berat lahir dengan umur kehamilan, berat bayi lahir dapat dikelompokan: bayi kurang bulan (BKB), yaitu bayi yang dilahirkan dengan masa gestasi < 37 minggu (259 hari). Bayi cukup bulan (BCB), bayi yang dilahirkan dengan masa gestasi antara 37-42 minggu (259 293 hari), dan Bayi lebih bulan (BLB), bayi yang dilahirkan dengan masa gestasi $>42$ minggu (294 hari) (Kosim dkk, 2009, p.1213).

Taksiran berat janin yang mendasarkan pada tinggi fundus uteri ini, bersifat universal tanpa mempertimbangkan keadaan lokal, misalnya ras, genetik dan kondisi geografis, dengan demikian perlu 
adanya suatu upaya klarifikasi untuk mengukur sejauh mana ketepatan teori ini untuk menaksir berat badan bayi baru lahir (Julianty, 2009).

Pengukuran tinggi fundus uteri di atas simfisis pubis digunakan sebagai salah satu indikator untuk menentukan kemajuan pertumbuhan janin. Pengukuran tinggi fundus uteri dapat dijadikan perkiraan usia kehamilan. Tinggi fundus yang stabil/tetap atau turun merupakan indikasi adanya retardasi pertumbuhan janin, sebaliknya tinggi fundus yang meningkat secara berlebihan mengidentifikasi adanya jumlah janin lebih dari satu atau kemungkinan adanya hidramnion. (Julianty, 2009).

Pengukuran tinggi fundus uteri harus dilakukan dengan teknik yang konsisten pada setiap kali pengukuran dan dengan menggunakan alat yang sama, alat ukur ini dapat berupa metlyn atau dengan menggunakan pelvimeter. Posisi yang dianjurkan pada saat melakukan pengukuran tinggi fundus uteri adalah klien berbaring (posisi supinasi) dengan kepala sedikit terangkat (menggunakan satu bantal) dan lutut diluruskan. Alat ukur (pita atau pelvimeter) diletakkan di bagian tengan abdomen dan diukur mulai dari atas simphisis pubis hingga batas atas fundus. (Julianty, 2009).

Pada posisi terlentang (supinasi) lebih akurat dikarenakan pada posisi tersebut kantong kehamilan atau kandungan dapat terukur secara penuh atau keseluruhan, dibandingkan dengan posisi setengah duduk (semi fowler) karena adanya tekukkan sehingga ujung uterus tidak teraba secara utuh disebabkan oleh ketebalan kulit yang bertambah, maka untuk pengukuran tinggi fundus uteri yang akurat menghitung taksiran berat badan janin menurut rumus Johnson Thausack menggunakan posisi terlentang (supinasi). (Julianty, 2009)

Sebenarnya tidak ada hubungan posisi semi fowler dengan taksiran berat badan janin melalui pengukuran tinggi fundus uteri secara teoritis. Namun pada saat pengukuran tinggi fundus uteri MC. Donald menggunakan posisi semi fowler untuk mengurangi resiko kekurangan suplai oksigen dalam darah ke otak, hanya pada penelitian ini menjelaskan pengukuran tinggi fundus uteri dengan posisi semi folwer tidak akurat disebabkan oleh volume ketebalan kulit pada ibu hamil bertambah, sehingga lengkungan uterus pada saat pengukuran tinggi fundus uteri tidak teraba jelas.

\section{KESIMPULAN}

Hasil perhitungan TBBJ menggunakan rumus Johnson Thausack TBBJ yaitu TBBJ $\leq 2500$ gram terdapat 3 orang (8,3\%) dan TBBJ 2500-4000 gram terdapat 33 orang $(91,7 \%)$. Hasil penimbangan bahwa berat badan bayi lahir menggunakan rumus Johnson Thausack yaitu BBBL 2500-4000 gram terdapat 36 orang $(100 \%)$. Tidak terdapat perbedaan yang signifikan antara akurasi hasil taksiran berat badan janin menurut Johnson Thausack dengan berat badan bayi lahir menggunakan posisi semi fowler

Dapat menjadi masukan bagi petugas kesehatan dalam upaya menurunkan AKB (angka kematian bayi) yang disebabkan oleh komplikasi persalinan karena distosia, asfiksia, berat badan bayi rendah $(<2500$ gram). Melalui pemeriksaan tinggi fundus uteri pada ibu hamil dapat mendeteksi secara dini komplikasi tersebut dengan cara mengetahui taksiran berat badan janin.

\section{DAFTAR PUSTAKA}

Badan Kependudukan dan Keluarga Berencana Nasional, Badan Pusat Statistik, Kementerian Kesehatan, 2013. Survei Demografi dan Kesehatan Indonesia. 2012. Jakarta

Badan Penelitian dan Pengembangan Kesehatan Kemenkes RI. 2010. Riset Kesehatan Dasar, Jakarta: Depkes

Bobak, Irene M. dkk.2005. Buku Ajar Keperawatan Materntas. Edisi 4. Jakarta: EGC

Cuningham, F. G, Gant, N.F, Leveno KJ, Gilstrap, Lc, Haulth, Jc, Wenstrom, KD. 2007. Obstetri William, Vol. 1 Edisi 21, Jakarta: EGC 
Departemen Kesehatan Republik Indonesia, 2008. Perawatan Bayi Berat Lahir Rendah (BBLR) dengan Metode kanguru. Jakarta: Health Technology Assessment Indonesia.

Djaja, S., D. Hapsari, N. Sulistyowati, Dina dan B. Lolong, 2009. Peran Faktor Sosio-Ekonomi, Biologi dan Pelayanan Kesehatan terhadap Kesakitan dan Kematian Neonatal. Jakarta: Departemen Kesehatan RI, Majalah Kedokteran Indonesia, volume 59, nomor 8

Herianto, S.M. Sarumpaet, dan Rasmaliah, 2012. Faktor-Fator yang Mempengaruhi Terjadinya Asphyxia Neonatorum di Rumah Sakit Umum ST Elisabeth Medan Tahun 2007-2012. Medan: Universitas Sumatera Utara.

Hidayat A. Aziz Alimul, Musrifatul. 2008. Keterampilan Dasar Praktik Klinik untuk Kebidanan. Jakarta : Salemba Medika

Mandriwati. 2008. Penuntun Belajar Asuhan Kebidanan Ibu Hamil. Jakarta : EGC

Notoatmodjo, Soekidjo. 2010. Metodologi Penelitian Kesehatan. Jakarta : Rineka Cipta

Prasetyowati, Fibrila. F, Martini, 2009. Perbandingan Hasil Tafsiran Berat Badan Janin Menurut Johnson Thausack dan Niswander dengan Berat Badan Bayi Lahir Pada lbu Inpartu di BPS Kab. Lampung Utara." Metro Sai Wawai" Vol. 11

Prawirohardjo, Sarwono. 2009. Pelayanan Kesehatan Maternal dan Neonatal. Jakarta: Bina Pustaka

Saragih E, 2011. Perilaku lbu Primipara dalam Merawat Bayi Baru Lahir di Kabupaten Sukaraja Kecamatan Medan Maimun. Skripsi Fakultas Keperawatan Universitas Sumatera Utara

Sujawerni, Wiratna. 2014. SPSS Untuk Penelitian, Yogyakarta: Pustaka Baru Press

Suritinah, 2008. Buku Pintar Kehamilan dan Persalinan, Jakarta: P.T. Gramedia Pustaka Utama
Winkjosastro, H. 2008. Ilmu kebidanan. Jakarta: Yayasan Bina Pustaka Sarwono Prawirohardjo. 